\title{
The Use of Natural Products for the Treatment of Female Sexual Dysfunction: A Systematic Review of Randomized Clinical Trials
}

\author{
Ana Rosa Jurado1,2, Mirian Jouda-Benazouz ${ }^{1}$, Loreto Mendoza-Huertas ${ }^{1}$, Nicolás Mendoza ${ }^{*}$ \\ ${ }^{1}$ Departament of Obstetrics and Gynecology, University of Granada, Granada, Spain \\ ${ }^{2}$ Instituto Europeo de Sexologia, Marbella, Málaga, Spain \\ Email: anarosajuradolopez@gmail.com,mirianjouda7@gmail.com, *nicomendoza@telefonica.net, loretomendoza2@gmail.com
}

How to cite this paper: Jurado, A.R., Jouda-Benazouz, M., Mendoza-Huertas, L. and Mendoza, N. (2020) The Use of Natural Products for the Treatment of Female Sexual Dysfunction: A Systematic Review of Randomized Clinical Trials. Advances in Sexual Medicine, 10, 56-69.

https://doi.org/10.4236/asm.2020.102004

Received: January 3, 2020

Accepted: April 23, 2020

Published: April 26, 2020

Copyright $\odot 2020$ by author(s) and Scientific Research Publishing Inc. This work is licensed under the Creative Commons Attribution International License (CC BY 4.0).

http://creativecommons.org/licenses/by/4.0/

(c) (i) Open Access

\begin{abstract}
Female sexual dysfunction (FSD) affects $40 \%$ of the world's females, most of which are disorders linked to desire or interest/excitement. Whilst all types of therapy that attempt to improve female sexual desire have long been established, the results are contradictory. Objective: To analyze all available evidence to validate the effectiveness of natural therapies in the treatment of FSD. Method: The study was registered at http://www.prospero.org (CRD42019127700). We searched the Institute for Scientific Information Web of Knowledge, MEDLINE, Pubmed, Scopus and Cochrane databases for all articles published in peerreviewed journals in April 2019 (in any language). The PICOS standard is women with FSD; (intervention) of any type of Natural therapy; (outcome) primary outcome: frequency of changes, severity, and average mean scores on sexual symptoms measured with a validated instrument, secondary outcome: quality of life; (study design) and randomized clinical trial (RCT). Results: The literature search strategy identified 95 articles, 81 of which were excluded at the different search stages. Finally, we systematically reviewed 15 RCTs, 11 of which referred to primary FSD, and four of which analyzed women with drug-induced FSD (DFSD). Most of them analyzed hypoactive sexual desire disorder. Although differences related to placebo were found in most people, the majority of the studies are considered to be of poor quality and low external effectiveness. Conclusion: Although the quality of the evidence is not high, most natural product interventions appear to improve FSD, particularly hypoactive sexual desire disorders including those categorized as primary and drug-induced.
\end{abstract}

\section{Keywords}

Female Sexual Dysfunction, Drug-Induced Female Sexual Dysfunction, Sexual Health, Natural Therapies 


\section{Introduction}

It is estimated that some type of sexual dysfunction affects $40 \%$ of females worldwide, with most being manifest as desire or interest/excitement disorders [1]. The majority of postmenopausal women report symptoms that affect their sexual health, which can either be secondary to vulvovaginal atrophy (VVA) or the result of disorders of desire, interest, or excitement [2]. In this regard, there is a close relationship between female sexual dysfunction (FSD) and poor quality of life, which is often associated with psycho-affective problems such as anxiety, melancholy, low self-esteem, or marital problems [3]. However, there are significant problems regarding the manner in which various studies have evaluated "sexual dysfunction" or distress in women, including the use of non-validated instruments [4].

Moreover, the use of any type of formulation that attempts to improve female sexual desire has long been established, although the results are contradictory. A recent meta-analysis has also indicated that placebo accounts for almost $70 \%$ of FSD treatment, meaning that any interventions studied to date have reached a lower level than placebo, which emphasizes the need for more treatments that are effective for any type of FSD [5]. However, certain biases are observed in the conclusions of this meta-analysis, such as that the different conditions and different treatments for FSD in this single meta-analysis, or that placebo rates are also high for other conditions or other treatments for women.

The purpose of this systematic review is to analyze all available evidence to validate the effectiveness of natural therapies in the treatment of FSD.

\section{Methods}

\subsection{Selection of Studies}

We searched the Institute for Scientific Information Web of Knowledge, MEDLINE, Pubmed, Scopus, and Cochrane databases for all articles (in any language) published in peer-reviewed journals in April 2019 using the search strategy described in Appendix. The search criteria were adjusted for each database as well as the database-specific filters available. Other publications were identified by manually searching through a reference list of papers identified by the search as well as key words, which were hand-searched to select additional publications. We also considered those that were in press in peer-reviewed journals and available online prior to publication.

The PICOS (Population, Intervention, Comparison, Outcomes, Study design) criteria are developed a priori to guide the scope of the review and the procedures, selection, and synthesis of the literature search. The selection criteria were as follows: (population) FSD female; (intervention) any type of natural therapy; (outcome) primary outcome: change in frequency, severity and average mean scores of sexual symptoms measured with a validated instrument; secondary outcome: Quality of life; (study design) randomized clinical trial (RCT). Complete articles that meet the inclusion criteria were reviewed in detail. Other related papers are 
for reference purposes only.

The exclusion criteria were: other etiologies for FSD and prevention (or treatment) of the FSD.

Key words: female sexual dysfunction, drug induced female sexual dysfunction, sexual health, natural therapies.

PICO question: Can natural products improve FSD, both primary and drug induced?

\subsection{Data Extraction}

Two independent reviewers (NM and MJ) extracted the data from the included studies using a specifically developed data extraction form based on the selection criteria. The extracted information includes a description of the study, participants, and findings based on the above results. Where there was no data (method or result) of interest in the published paper, we contacted the authors by email.

\subsection{Assessment of Study Quality and Data Synthesis}

We conducted a systematic review in accordance with PRISMA [6]. The authors (NM, MJ, and AR) conducted an independent search and screening studies to include, extract and examine data and synthesize the results. The authors (NM, MJ, AR and $\mathrm{CN}$ ) independently determined the adequacy and primary methodological characteristics of the study design to determine the validity of the study. Any disagreements were resolved through discussion and consensus.

\section{Results}

As shown in Figure 1 (PRISMA flow diagram), the literature search strategy identified 96 articles, 81 of which were excluded at different stages of the search. Finally, we systematically reviewed 15 RCTs [7]-[21], 11 of which mentioned the primary FSD [8] [13] [15] [21] or hypoactive sexual desire disorders (HSDD) [7] [9] [10] [11] [12] [14] [20]. The other four RCTs analyzed women with DIFSD [16] [17] [18] [19]. A summary of the main features of the selected studies (population, intervention, comparison, outcomes, and study design) is displayed in Table 1.

Regarding the characteristics of the intervention, in FSD or HSDD, Tribulus terrestris was used for four studies [9] [12] [13] [14], visnadine (Ammi visnaga) was used for three [15] [20] [21], and ArginMax was used for one [7], red clover (Trifoliumpratense) is used in one [8], Libifem (Trigonellafoenum-graecum) in one [10], Elaeagnus angustifolia in one [11]. Ginkgo biloba leaves were used in one study [16], saffron (Crocus sativus) was used in one [17], and Rosa damascena oil was used in two studies [18] [19].

Placebo-related differences were found in 9 of the studies [7] [8] [9] [10] [15] [16] [17] [18] [19] [21]. One of the interventions with Tribulus terrestris (750 $\mathrm{mg} / \mathrm{day}$ for 4 weeks), found placebo-related differences in terms of desire, arousal, 


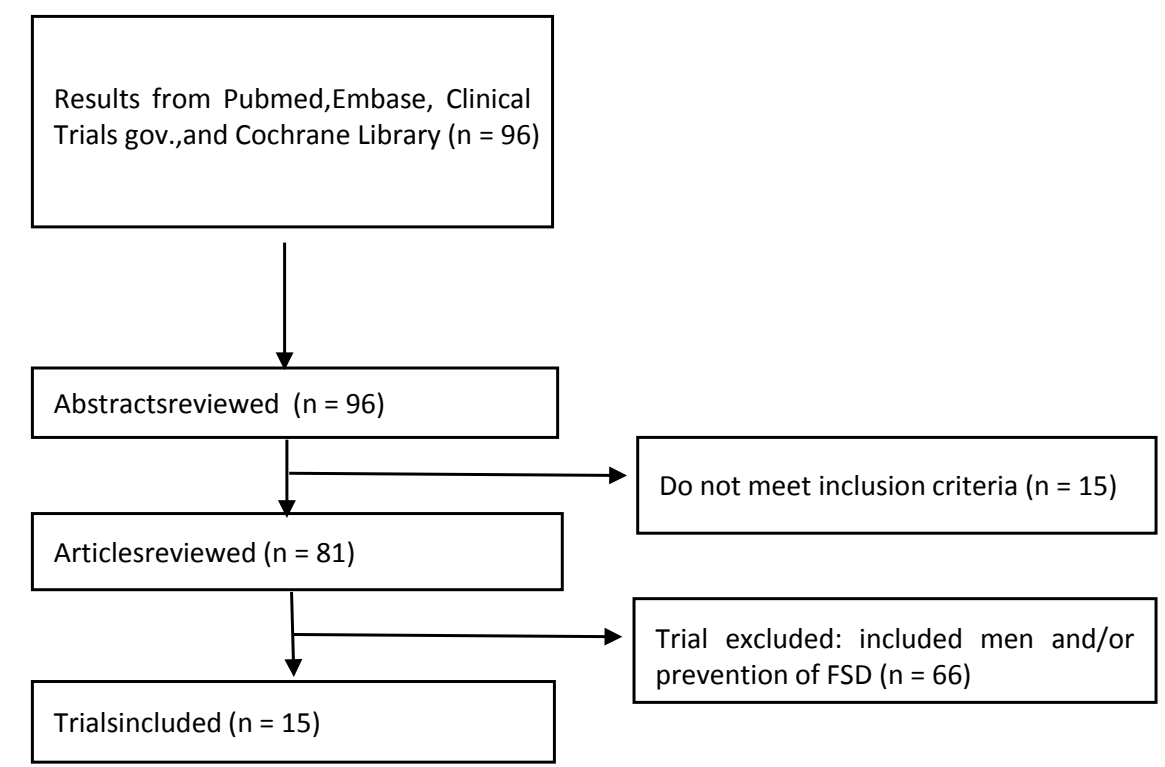

Figure 1. Flow chart of studies.

Table 1. Summary of findings in female sexual dysfunction.

\begin{tabular}{|c|c|c|c|c|c|}
\hline Authors & Method & Population & Intervention & Objective & Main results \\
\hline $\begin{array}{l}\text { Ito et al. } \\
2006[7]\end{array}$ & RCT & $\begin{array}{l}108 \text { women with } \\
\text { HSDD } \\
\text { Age: } 22-73\end{array}$ & $\begin{array}{ll}\text { - } & \operatorname{ArginMax}^{\mathrm{a}}(\mathrm{n}=55) \\
\text { - } & \text { Placebo }(\mathrm{n}=53) \\
\text { - } & 8 \text { weeks }\end{array}$ & Efficacy on HSDD & $\begin{array}{l}\text { Improvement in postmenopausal } \\
\text { women }(p=0.008)\end{array}$ \\
\hline $\begin{array}{l}\text { Chedraui et } \\
\text { al. } 2006[8]\end{array}$ & Crossover RCT & $\begin{array}{l}60 \text { women with } \\
\text { FSD } \\
\text { Age: }>40\end{array}$ & $\begin{array}{l}\text { - } \quad \text { Red clover }{ }^{\mathrm{b}}, \\
80 \mathrm{mg} / \mathrm{day}(\mathrm{n}=30) \\
\text { - } \quad \text { Placebo }(\mathrm{n}=30) \\
\text { - } \quad 3+3 \text { months }\end{array}$ & Efficacy on FSD & $\begin{array}{l}\text { Improvement in dyspareunia, } \\
\text { vaginal dryness and decreased } \\
\text { libido }(p<0.05)\end{array}$ \\
\hline $\begin{array}{l}\text { Akhtari et } \\
\text { al. } 2014[9]\end{array}$ & $\begin{array}{c}\text { RCT } \\
\text { IIRCT2012111111 } \\
1425 \mathrm{~N} 1\end{array}$ & $\begin{array}{l}67 \text { women with } \\
\quad \text { HSDD } \\
\text { Average age: } 36\end{array}$ & $\begin{array}{l}\text { Tribulus terrestris, } \\
750 \mathrm{mg} / \text { day } \\
(\mathrm{n}=33) \\
\text { - } \quad \text { Placebo }(\mathrm{n}=34) \\
\text { - } 4 \text { weeks }\end{array}$ & Efficacy on HSDD & $\begin{array}{l}\text { Improvement on total FSFI ( } p< \\
0.001) \text {, desire }(p<0.001) \text {, arousal } \\
(p=0.037) \text {, lubrication }(p<0.001) \text {, } \\
\text { satisfaction }(p<0.001) \text { pain }(p= \\
0.041)\end{array}$ \\
\hline $\begin{array}{l}\text { Rao et al. } \\
2015[10]\end{array}$ & $\begin{array}{c}\text { RCT } \\
12611001031954 .\end{array}$ & $\begin{array}{l}80 \text { women with } \\
\text { HSDD } \\
\text { Average Age: } 34.9 \\
\quad(20-49)\end{array}$ & $\begin{array}{l}\text { Trigonella foenum- } \\
\text { graecum }^{\mathrm{d}} \text { seed extract } \\
(\text { Libifem }) 600 \mathrm{mg} / \mathrm{day} \\
(\mathrm{n}=40) \\
\text { - } \quad \text { Placebo }(\mathrm{n}=40) \\
\text { - } 2 \text { menstrual cycles }\end{array}$ & $\begin{array}{l}\text { Primary: efficacy } \\
\text { on HSDD } \\
\text { - } \\
\text { Secondary: E2 } \\
\text { and testosterone }\end{array}$ & $\begin{array}{l}\text { Improvement in sexual desire and } \\
\text { arousal vs placebo }(p<0.05)\end{array}$ \\
\hline $\begin{array}{l}\text { Zeinal- } \\
\text { zadeh et al. } \\
2016[11]\end{array}$ & $\begin{array}{c}\text { RCT } \\
201205219818 \mathrm{~N} 1\end{array}$ & $\begin{array}{l}125 \text { women with } \\
\text { HSSD } \\
\text { Age: } 18-40\end{array}$ & $\begin{array}{ll}\text { - } & \text { Elaeagnus angustiflora } \\
& 4.5 \mathrm{~g}(\mathrm{n}=41) \\
\text { - } & \text { Sildenafil } 50 \mathrm{mg}(\mathrm{n}=42) \\
\text { - } & \text { Placebo }(\mathrm{n}=42) \\
\text { - } & 4 \text { weeks }\end{array}$ & $\begin{array}{l}\text { Primary: efficacy } \\
\text { on HSDD } \\
\text { - Secondary: TSH } \\
\text { and prolactin }\end{array}$ & $\begin{array}{l}\text { Only sildenafil decreased anxiety } \\
\text { resulting from sexual dysfunction }\end{array}$ \\
\hline $\begin{array}{l}\text { Postigo et } \\
\text { al. } 2016 \\
{[13]}\end{array}$ & $\begin{array}{c}\text { RCT } \\
\text { ISSN0100-7203 }\end{array}$ & $\begin{array}{l}60 \text { women with } \\
\text { FSD. } \\
\text { Average age: } 55\end{array}$ & $\begin{array}{ll}\text { - } & \text { Tribulus terrestris } \\
& 750 \mathrm{mg} / \text { day }(\mathrm{n}=30) \\
\text { - } & \text { Placebo }(\mathrm{n}=30) \\
\text { - } & 90 \text { days }\end{array}$ & Efficacy on FSD & $\begin{array}{l}\text { Improvements in all domains but } \\
\text { NO differences respecting placebo }\end{array}$ \\
\hline
\end{tabular}




\section{Continued}

\begin{tabular}{|c|c|c|c|c|c|}
\hline $\begin{array}{c}\text { Souza et al. } \\
2016[12]\end{array}$ & $\begin{array}{c}\text { RCT } \\
\text { NCT01975694 }\end{array}$ & $\begin{array}{l}45 \text { women with } \\
\text { HSDD } \\
\text { Average age: } 53\end{array}$ & $\begin{array}{ll}\text { - } & \text { Tribulus terrestris } \\
& 750 \mathrm{mg} / \mathrm{day}(\mathrm{n}=20) \\
\text { - } & \text { Placebo }(\mathrm{n}=16) \\
\text { - } & 12 \text { weeks }\end{array}$ & $\begin{array}{l}\text { - Primary: efficacy } \\
\text { of HSDD } \\
\text { - Secondary: } \\
\text { testosterone }\end{array}$ & $\begin{array}{l}\text { Improvements in total FSFI score } \\
\text { and most domains, increase of free } \\
\text { and bioavailable testosterone } \\
\text { NO differences respecting placebo }\end{array}$ \\
\hline $\begin{array}{l}\text { Vale et al. } \\
2018[14]\end{array}$ & $\begin{array}{c}\text { RCT } \\
\text { NCT01971099 }\end{array}$ & $\begin{array}{l}40 \text { women with } \\
\text { HSDD } \\
\text { Age: } 18-44\end{array}$ & $\begin{array}{ll}\text { - } & \text { Tribulus terrestris } \\
& 750 \mathrm{mg} / \text { day }(\mathrm{n}=20) \\
\text { - } & \text { Placebo }(\mathrm{n}=20) \\
\text { - } & 120 \text { days }\end{array}$ & $\begin{array}{l}\text { - Primary: efficacy } \\
\text { of HSDD } \\
\text { - Secondary: } \\
\text { testosterone }\end{array}$ & $\begin{array}{l}\text { Improvements in total FSFI score } \\
\text { and most domains, increase of free } \\
\text { and bioavailable testosterone } \\
\text { NO differences respecting placebo }\end{array}$ \\
\hline $\begin{array}{l}\text { Bernorio et al. } \\
2018 \text { [15] }\end{array}$ & RCT Pilot study & $\begin{array}{l}60 \text { women with } \\
\text { FSD } \\
\text { Age: } 18-60\end{array}$ & $\begin{array}{ll}\text { - } & \text { Visnadine spray }(\mathrm{n}=30) \\
\text { - } & \text { Placebo }(\mathrm{n}=30) \\
\text { - } & 30 \text { days }\end{array}$ & Efficacy on FSD & $\begin{array}{l}\text { Improvements in sexual function } \\
\text { (FSFI) in women with/without FSD } \\
\text { respect to placebo }(p<0.05)\end{array}$ \\
\hline $\begin{array}{l}\text { Caruso et al. } \\
2018[21]\end{array}$ & $\begin{array}{c}\text { RCT } \\
\text { crossover study }\end{array}$ & $\begin{array}{l}38 \text { women with } \\
\text { HSDD } \\
\text { Age: } 25-40\end{array}$ & $\begin{array}{l}\text { - } \quad \text { Visnadine spray on demand } \\
(\mathrm{n}=30) \\
\text { - } \quad \text { Visnadine spray daily } \\
(\mathrm{n}=30) \\
\text { - } 60 \text { days }\end{array}$ & Efficacy on HSDD & Both improved HSDD $(p<0.001)$ \\
\hline $\begin{array}{l}\text { Caputo et al. } \\
2018[21]\end{array}$ & RCT pilot study & $\begin{array}{l}69 \text { women with } \\
\text { FSD } \\
\text { Average } \\
\text { Age: } 35-38\end{array}$ & $\begin{array}{l}\text { - } \quad \text { Visnadine oil }(\mathrm{n}=30) \\
\text { - } \quad \text { Placebo }(\mathrm{n}=30) \\
\text { - } 8 \text { weeks }\end{array}$ & Efficacy on FSD & Improvements on FSFI $(p<0.05)$ \\
\hline $\begin{array}{l}\text { Meston et al. } \\
2008[16]\end{array}$ & RCT & $\begin{array}{l}63 \text { women with } \\
\text { FSD }+36 \text { with } \\
\text { DFSD } \\
\text { (antidepressant) } \\
\text { Age: } 18-65 .\end{array}$ & $\begin{array}{ll}\text { - } & \text { Ginkgo biloba }{ }^{\mathrm{f}} \\
& 300 \mathrm{mg} / \mathrm{day}(\mathrm{n}=19) \\
\text { - } & \text { Ginkgo biloba }+ \text { sex therapy } \\
& (\mathrm{n}=14) \\
\text { - } & \text { Sex therapy }(\mathrm{n}=19) \\
\text { - } & \text { Placebo }(\mathrm{n}=16) \\
\text { - } & 8 \text { weeks }\end{array}$ & Efficacy on DIFSD & $\begin{array}{l}\text { Ginkgo biloba + sex therapy } \\
\text { increased desire respect placebo } \\
(p<0.05) \text {, } \\
\text { but not Ginkgo biloba alone } \\
\text { Sex therapy alone enhanced orgasm } \\
\text { function respect placebo }(p<0.05) \text {. }\end{array}$ \\
\hline $\begin{array}{l}\text { Kashani et al. } \\
2013 \text { [17] }\end{array}$ & $\begin{array}{c}\text { RCT } \\
138711121556 \mathrm{~N} \\
3\end{array}$ & $\begin{array}{l}38 \text { women with } \\
\text { DFSD (fluoxetine) } \\
\text { Age: } 18 \text { - } 45\end{array}$ & $\begin{array}{ll}\text { - } & \text { Saffrong } \\
& 30 \mathrm{mg} / \text { day }(\mathrm{n}=19) \\
\text { - } & \text { Placebo }(\mathrm{n}=19) \\
\text { - } & 4 \text { weeks }\end{array}$ & Efficacy on DIFSD & $\begin{array}{l}\text { Improvement in total FSFI ( } p< \\
0.001) \text {, arousal }(p=0.028) \\
\text { lubrication }(p=0.035), \text { and pain } \\
(p=0.016) \text { but not in desire, } \\
\text { satisfaction and orgasm. }\end{array}$ \\
\hline $\begin{array}{c}\text { Farnia et al. } \\
2015[18]\end{array}$ & $\begin{array}{c}\text { RCT } \\
\text { IRCT201310011 } \\
4333 \mathrm{~N} 9\end{array}$ & $\begin{array}{l}61 \text { women with } \\
\text { DFSD (SSRI) } \\
\text { Age: } 34\end{array}$ & $\begin{array}{ll}\text { - } & \text { Rosa damascena oil } \\
& 2 \mathrm{ml} / \text { day }(\mathrm{n}=31) \\
\text { - } & \text { Placebo }(\mathrm{n}=31) \\
\text { - } & 8 \text { weeks }\end{array}$ & Efficacy on DIFSD & $\begin{array}{l}\text { No Improvements on FSFI } \\
\text { compared to placebo }\end{array}$ \\
\hline $\begin{array}{l}\text { Farnia et al. } \\
2017 \text { [19] }\end{array}$ & $\begin{array}{c}\text { RCT } \\
\text { IRCT201509152 } \\
3705 \mathrm{~N} 2\end{array}$ & $\begin{array}{l}50 \text { women with } \\
\text { DFSD } \\
\text { (methadone) } \\
\text { Age: } 38.8\end{array}$ & $\begin{array}{l}\text { - } \quad \text { Rosa damascena oil }{ }^{\mathrm{h}} \\
2 \mathrm{ml} / \text { day }(\mathrm{n}=25) \\
\text { - } \quad \text { Placebo }(\mathrm{n}=25) \\
\text { - } 8 \text { weeks }\end{array}$ & $\begin{array}{c}\text { Efficacy on DIFSD } \\
\text { Sex hormones }\end{array}$ & $\begin{array}{l}\text { Improvements on FSFI }(p<0.05) \\
\text { and sex hormones compared to } \\
\text { placebo }\end{array}$ \\
\hline
\end{tabular}

Abbreviations: DFSD: Drug-induced Female Sexual Dysfunction; FSFI: Female Sex Function Index; HSDD: Hypoactive Sexual Desire Disorder; RCT: Randomized Control Trial; Sexual Function Questionnaire; SFI: Sexual Function Index; SQ-F: Sexual Quotient-female; SSRI: Selective Serotonin Reuptake Inhibitor; TSH: Thyroid Stimulating Hormone.

${ }^{a}$ ArginMax contains L-arginine, ginseng, ginkgo, damiana, multivitamins and minerals; ${ }^{b}$ red clover extract (MF11RCE) 80 mg isoflavones; 'ethanolic extract (60\% aamyrine); ' equivalent to $9.9 \mathrm{~g}$ dry herb, standardised to a minimum $50 \%$ saponin glycosides; ${ }^{e}$ flowers extract; ${ }^{\mathrm{f}}$ standardized $G$.

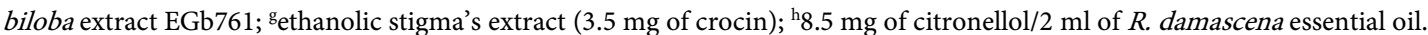


lubrication, satisfaction and pain, along with Female Sexual Function Index (FSFI) total score [9]. The remaining interventions with Tribulus terrestrisim proved scores in all domains, but failed to obtain differences with respect to placebo.

Visasdine is a local treatment applied to the vulvar area $10 \mathrm{~min}$ before sexual stimulation. The 3 Visadine interventions are applied in different ways: One of them evaluated the use of spray on demand [15], another evaluated both on demand and daily use, without placebo group [20], whilst a further study assessed the use of Visnadine oil [21]. Both spray and oil produced differences in the FSFI score with respect to placebo [15] [21], although the oil intervention was a pilot study. The other study found results to indicate the efficacy of both daily and on-demand use in women with HSDD [20].

ArginMax was tested in pre, peri, and postmenopausal women, and was found to produce differences with respect to placebo in postmenopausal women with HSDD [7]. Red clover oral supplement, administered at a dose of $80 \mathrm{mg} /$ day for 3 months, improved $(p<0.05)$ dyspareunia, vaginal dryness, and libido when evaluating women aged over 40 years with FSD [8]. With regard to younger women (20 - 49) with HSDD, the use of Libifem for two menstrual cycles improved sexual desire and arousal when compared with placebo [10].

Studies evaluating the efficacy on DIFSD were concerned with interventions using Ginko biloba [16], Saffron [17], and Rosa damascene [18] [19]. DIFSD was a result of antidepressant medication in three of the studies [16] [17] [18]. Only Ginkgo Biloba and Saffron were found to increase sexual function with respect to placebo in these interventions. The intervention with Ginko biloba consisted of evaluating four groups [16]: one group received $300 \mathrm{mg} /$ day alone, another group received the same dose along with sexual therapy, a further group received sexual therapy alone and a final group were given placebo. Significant differences were found for the Ginkgo biloba + sexual therapy group vs placebo, but not for the group given Ginkgo biloba alone, in terms of increasing sexual desire. The Safron intervention ( $30 \mathrm{mg} /$ day for 4 weeks) improved sexual function by increasing arousal, lubrication, and reducing pain, but had no effect on sexual desire, satisfaction and orgasm in women with DIFSD due to Fluoxetine [17].

Rosa damascena oil ( $2 \mathrm{ml} /$ day for 8 weeks) failed to increase sexual function when DIFSD was the result of antidepressant medication [18], but it increased FSFI with respect to placebo when DIFSD was due to methadone [19].

In the majority of the works, FSD (predominantly HSDD) was analyzed as the primary goal of the study. The results were mainly reported with regard to FSFI. In terms of the quality of the studies, most are considered to be of medium to low quality (Table 2), mainly due to the risk of bias, heterogeneity, and small sample size. In addition, the external validity of the studies are very low, since many natural products have been tested in eastern countries where volunteers must be heterosexual and married, and in many cases, the husband has signed a consent form. 
Table 2. Quality of studies.

\begin{tabular}{|c|c|c|c|c|c|c|c|}
\hline Authors & Random & Allocation & Double-blind & FSD & FSFI & Drop out (\%) & Adverse effects \\
\hline Ito et al. 2006 [7] & - & - & + & HSDD & FSFI modified & 0 & $\begin{array}{l}\text { No significant difference } \\
\text { in adverse effects }\end{array}$ \\
\hline Chedraui et al. 2006 [8] & - & - & + & + & KI & 11.7 & Not described \\
\hline Akhtari et al. 2014 [9] & + & + & + & HSDD & + & 10.4 & $\begin{array}{l}\text { Only one patient reported } \\
\text { grade } 1 \text { abdominal cramp. }\end{array}$ \\
\hline Rao et al. 2015 [10] & + & + & + & HSSD & + & 0 & $\begin{array}{l}\text { No significant difference } \\
\text { in adverse effects }\end{array}$ \\
\hline Zeinalzadeh et al. 2016 [11] & + & + & + & HSSD & + & 10.7 & Not described \\
\hline Postigo et al. 2016 [13] & - & - & + & FSD & SQ-F, FIEI & 0 & $\begin{array}{l}\text { No significant difference } \\
\text { in adverse effects }\end{array}$ \\
\hline De Souza et al. 2016 [12] & + & - & + & HSDD & + & 20 & Not described \\
\hline Vale et al. 2017 [14] & - & - & + & HSDD & + & 37.5 & Not described \\
\hline Bernorio et al. 2018 [15] & + & + & + & FSD & + & 3.3 & $\begin{array}{l}\text { Both products were } \\
\text { very well tolerated }\end{array}$ \\
\hline Caruso et al. 2018 [20] & + & - & - & HSDD & + & 26.9 & Not described \\
\hline Caputo et al. 2018 [21] & - & - & - & FSD & + & 3.3 & Not described \\
\hline \multicolumn{8}{|c|}{ DRUG-INDUCED FSD (DIFSD) } \\
\hline Meston et al. 2008 [16] & - & - & + & FSD + DIFSD & + & 19.1 & Not described \\
\hline Kashani et al. 2012 [17] & - & - & + & DIFSD & + & 10.5 & $\begin{array}{l}\text { Described with no } \\
\text { differences }\end{array}$ \\
\hline Farnia et al. 2015 [18] & + & - & + & DIFSD & + & 0 & No side effects \\
\hline Farnia et al. 2017 [19] & + & - & + & DIFSD & + & 0 & Not described \\
\hline
\end{tabular}

Abbreviations: DFSD: Drug-induced Female Sexual Dysfunction; FIEI: Female Intervention Efficacy Index; FSD: Female Sexual Dysfunction; FSFI: Female Sex Function Index; HSDD: Hypoactive Sexual Desire Disorder; SQ-F: Sexual Quotient-female.

\section{Discussion}

FSD can affect most women of any age and condition, and when it does, it worsens the quality of their lives. In all of these cases, the predominance of desire disorder is marked by its frequency. An international consensus on the incidence and prevalence of sexual dysfunction shows that there are fewer data available on female dysfunctions than those of males, and FSD increases with age, most commonly with desire disorders, although they are often presented together. Trying to combine data is difficult because it is very different, but the case closest to our environment provides data to indicate an incidence of $20 \%$ in women under the age of $25 \%$ and $80 \%$ in women over 55 years of age [22].

\subsection{Why Was It Important to Conduct This Systematic Review?}

Despite the growing importance of FSD, there is a lack of research that can assess the efficacy of treatments. In addition, treatment of FSD usually does not include intervention using natural products. This systematic review included only RCTs for the natural intervention of FSD or DIFSD, but not for their prevention. 


\subsection{Strength}

This systematic review presents the state-of-the-art regarding evidence on the effectiveness of FSD natural product interventions. Our search identified 15 studies involving $1000 \mathrm{FSD}$ patients and 880 with HSDD as the primary symptom of FSD (185 of them were DIFSD). The strength of this evaluation is the systematic approach to identifying and assessing existing evidence of FSD-specific sexual intervention.

\subsection{What Is New about Other Similar Reviews?}

Our review is the first to systematically approach research into the FSD treatments. Two narrative reviews have provided updates on pharmacological treatments [23] and Chinese herbal medicine [24] and conducted a meta-analysis to assess the placebo effect of interventions for female sexual desire [5]. In our systematic review, we also included a study to assess the effectiveness of DIFSD treatment. The participants included 201 FSDs in women with depression as a result of medication.

\subsection{Limitations}

It was not possible to conduct a meta-analysis due to the heterogeneity of the research and the fundamental design and interventions used.

The studies included in this systematic review differed in design; whilst some studies included a comparison group without additional support for FSD, others compared intervention groups with an active control. Other important limitations to be noted are the small sample size of most studies, dropouts, and follow-up failures, along with the beneficial effects of placebo in many settings [5]. All studies except one [7] were highly biased because they included samples of less than 50 participants per trial. The trial differed not only in the content of the intervention but also in terms of the measurement of the outcome, which limited the joint analysis. In addition, the study lacked safety data. In general, the quality of evidence was lower for most of the included studies (see Table 2).

Regarding the diagnosis of FSD, all studies included heterosexual patients, mostly married couples. We suspect that in some studies, the diagnosis of FSD depends on the husband's opinion. In fact, this is one of the reasons why we did not accept some studies [25].

Women could suffer from DIFSD for a variety of reasons. However, none of the studies indicate whether the problems existed previously or whether they occur because of drugs, other emotional causes, stress, or whether aging itself could be the underlying cause of FSD. All these matters could be considered bias of our study.

\subsection{About the Strategies}

Generally, there are few RCTs that evaluate the natural treatment of FSD, while those that do exist include small sample sizes and report mixed results. 
The Tribulus terrestris extract contains protodioscin. Improvements in sexual function may be due to an increase in serum testosterone levels, particularly bioavailability and freeness, as this leads to an increase in the level of dehydroepiandrosterone (DHEA) in the human body. According to the results observed in [26], Tribulus terrestris may be an alternative to FSD in premenopausal and postmenopausal women, although it did not generate improvements with respect to placebo in three of the studies analyzed in this systematic review.

Turneradiffusa, commonly known as "Damiana", is a plant used as an aphrodisiac in Latin America, mainly in Mexico [27] showing experimental effects on nitric oxide and anxiolytic pathways. In the RCTs collected in our review, Damiana was mixed with L-arginine, ginkgo, and ginseng, and thus the improvement in FSFI values may be due to the combined effects of these agents.

Saffron (Crocus sativus) has anti-inflammatory, anti-oxidant, neuroprotective and anti-depressant pharmacological effects. Its effect on opioid receptors could explain the reduction of pain during sexual intercourse [28], and an increase in dopamine levels is evidence of an improvement in sexual arousal [29].

Visnadine is an active ingredient of $A m m i$ visnaga fruit, traditionally used for cardiovascular disorders, and has been thought to improve VVA [30].

Turneradiffusa and Ginkgo biloba appear to improve sexual desire by increasing free testosterone and improving vaginal vasodilation.

In traditional medicine, Turneradiffusa has been used to promote digestion, reduce inflammation and fight infections, treat sinusitis, and clear lung congestion. In addition, it is used as a galactogogue, which is associated with an increase in the size of the mother [31].

Ginkgo biloba has been used as a traditional Chinese herbal medicine with vascular protective function and has been proposed as a treatment for improving the sexual health of women over 50 years of age [32]. In the only article we have included in this systematic review, the effects of Gingko biloba alone on arousal did not differ from placebo [16].

Rosa damascena Mill is one of the most famous ornamental plants in the world, and is used primarily in the perfume industry. Traditionally it has been used as an astringent, analgesic, cardiac and intestinal supplement [33]. Farnia et al. found that this treatment improved male and female drug-induced sexual dysfunctions [34].

Libifem (Trigonella foenum-graecum) is a botanical extract rich in steroidal saponins, which has been found to have estrogenic and androgenic effects and generate improvements in male sexual function [35].

With respect to ArginMax (which contains L-arginine, ginseng, ginkgo, damiana, multivitamins and minerals), the Ito et al. study [7] used a 9-item scale, some items of which are similar to those in the 19-item FSFI and some of which are not, but none of which have been validated. This study also indicates that only 3 of the 9 items showed more success with the supplement than with placebo, and that the 3 differentiating items varied between the 3 subsets analyzed (premeno- 
pausal, perimenopausal, and postmenopausal women). Therefore, the Ito study failed to establish a primary endpoint and concluded success, even though no consistent pattern of success was evident either across subpopulations or across the majority of endpoints.

\subsection{Future Research}

Our systematic review has identified important areas for future research, particularly interventions that increase the impact of several natural products found in this review. In particular, a larger double-blind study should be conducted over a longer follow-up period to assess different treatment strategies for HSDD.

\section{Conclusion}

Although the quality of the evidence is not high, most natural product interventions appear to improve FSD, particularly HSDD, including primary and drug-induced forms of the disorder.

\section{Acknowledgements}

This article has been translated and edited by Your English Lab.

\section{Conflicts of Interest}

The authors declare no conflicts of interest regarding the publication of this paper.

\section{References}

[1] McCool, M.E., Zuelke, A., Theurich, M.A., Knuettel, H., Ricci, C. and Apfelbacher, C. (2016) Prevalence of Female Sexual Dysfunction among Premenopausal Women: A Systematic Review and Meta-Analysis of Observational Studies. Sexual Medicine Reviews, 4, 197-212. https://doi.org/10.1016/j.sxmr.2016.03.002

[2] Simon, J.A., Davis, S.R., Althof, S.E., Chedraui, P., Clayton, A.H., Kingsberg, S.A., Nappi, R.E., Parish, S.J. and Wolfman, W. (2018) Sexual Well-Being after Menopause: An International Menopause Society White Paper. Climacteric, 21, 415-427. https://doi.org/10.1080/13697137.2018.1482647

[3] Brotto, L., Atallah, S., Johnson-Agbakwu, C., Rosenbaum, T., Abdo, C., Byers, E.S., Graham, C., Nobre, P. and Wylie, K. (2016) Psychological and Interpersonal Dimensions of Sexual Function and Dysfunction. The Journal of Sexual Medicine, 13, 538-571. https://doi.org/10.1016/j.jsxm.2016.01.019

[4] Hayes, R.D., Dennerstein, L., Bennett, C.M. and Fairley, C.K. (2008) What Is the "True" Prevalence of Female Sexual Dysfunctions and Does the Way We Assess These Conditions Have an Impact? The Journal of Sexual Medicine, 5, 777-787. https://doi.org/10.1111/j.1743-6109.2007.00768.x

[5] Weinberger, J.M., Houman, J., Caron, A.T., Patel, D.N., Baskin, A.S., Ackerman, A.L., Eilber, K.S. and Anger, J.T. (2018) Female Sexual Dysfunction and the Placebo Effect: A Meta-Analysis. Obstetrics \& Gynecology, 132, 453-458. https://doi.org/10.1097/AOG.0000000000002733

[6] http://www.prisma-statement.org/statement.htm 
[7] Ito, T.Y., Polan, M.L., Whipple, B. and Trant, A.S. (2006) The Enhancement of Female Sexual Function with ArginMax, a Nutritional Supplement, among Women Differing in Menopausal Status. Journal of Sex \& Marital Therapy, 32, 369-378. https://doi.org/10.1080/00926230600834901

[8] Chedraui, P., Hidalgo, L., San Miguel, G., Morocho, N. and Ross, S. (2006) Red Clover Extract (MF11RCE) Supplementation and Postmenopausal Vaginal and Sexual Health. International Journal of Gynecology \& Obstetrics, 95, 296-297. https://doi.org/10.1016/j.ijgo.2006.08.013

[9] Akhtari, E., Raisi, F., Keshavarz, M., Hosseini, H., Sohrabvand, F., Bioos, S., Kamalinejad, M. and Ghobadi, A. (2014) Tribulus terrestris for Treatment of Sexual Dysfunction in Women: A Randomized Double-Blind Placebo-Controlled Study. Daru, 22, 40. https://doi.org/10.1186/2008-2231-22-40

[10] Rao, A., Steels, E., Beccaria, G., Inder, W.J. and Vitetta, L. (2015) Influence of a Specialized Trigonellafoenum-graecum Seed Extract (Libifem), on Testosterone, Estradiol and Sexual Function in Healthy Menstruating Women, a Randomized Placebo-Controlled Study. Phytotherapy Research, 29, 1123-1130.

https://doi.org/10.1002/ptr.5355

[11] Zeinalzadeh, S., Akbarzadeh, M., Mohagheghzadeh, A., Faridi, P. and Sayadi, M. (2016) Comparison of the Effects of Elaeagnus angustifolia Flower Capsule and Sildenafil Citrate Tablet on Anxiety Resulting from Sexual Dysfunction in Women Referring to the Selected Clinics of Shiraz University of Medical Sciences. Journal of Evidence-Based Integrative Medicine, 21, 186-193.

https://doi.org/10.1177/2156587215595777

[12] De Souza, K.Z., Vale, F.B. and Geber, S. (2016) Efficacy of Tribulus terrestris for the Treatment of Hypoactive Sexual Desire Disorder in Postmenopausal Women: A Randomized, Double-Blinded, Placebo-Controlled Trial. Menopause, 23, 1252-1256. https://doi.org/10.1097/GME.0000000000000766

[13] Postigo, S., Lima, S.M., Yamada, S.S., dos Reis, B.F., da Silva, G.M. and Aoki, T. (2016) Assessment of the Effects of Tribulus terrestris on Sexual Function of Menopausal Women. Revista Brasileira de Ginecologia e Obstetrícia, 38, 140-146. https://doi.org/10.1055/s-0036-1571472

[14] Vale, F.B.C., Zanolla Dias de Souza, K., Rezende, C.R. and Geber, S. (2018) Efficacy of Tribulus terrestrisfor the Treatment of Premenopausal Women with Hypoactive Sexual Desire Disorder: A Randomized Double-Blinded, Placebo-Controlled Trial. Gynecological Endocrinology, 34, 442-445. https://doi.org/10.1080/09513590.2017.1409711

[15] Bernorio, R., Piloni, S., Mori, G., Prunas, A., Bosoni, D. and Nappi, R.E. (2018) Efficacy and Tolerability of a Spray Formulation Containing Visnadine in Women Self-Reporting Sexual Symptoms: A Randomized Double-Blind Placebo-Controlled Pilot Study. Journal of Endocrinological Investigation, 41, 729-737. https://doi.org/10.1007/s40618-017-0801-0

[16] Meston, C.M., Rellini, A.H. and Telch, M.J. (2008) Short- and Long-Term Effects of Ginkgo biloba Extract on Sexual Dysfunction in Women. Archives of Sexual Behavior, 37, 530-547. https://doi.org/10.1007/s10508-008-9316-2

[17] Kashani, L., Raisi, F., Saroukhani, S., Sohrabi, H., Modabbernia, A., Nasehi, A.A., Jamshidi, A., Ashrafi, M., Mansouri, P., Ghaeli, P. and Akhondzadeh, S. (2013) Saffron for Treatment of Fluoxetine-Induced Sexual Dysfunction in Women: A Randomized Double-Blind Placebo-Controlled Study. Human Psychopharmacology, 28, 54-60. https://doi.org/10.1002/hup.2282 
[18] Farnia, V., Hojatitabar, S., Shakeri, J., Rezaei, M., Yazdchi, K., Bajoghli, H., Holsboer-Trachsler, E. and Brand, S. (2015) Adjuvant Rosa damascena Has a Small Effect on SSRI-Induced Sexual Dysfunction in Female Patients Suffering from MDD. Pharmacopsychiatry, 48, 156-163. https://doi.org/10.1055/s-0035-1554712

[19] Farnia, V., Tatari, F., Alikhani, M., Yazdchi, K., Taghizadeh, M., SadeghiBahmani, D., Karbasizadeh, H., Holsboer-Trachsler, E. and Brand, S. (2017) Rosa damascena Oil Improved Methadone-Related Sexual Dysfunction in Females with Opioid Use Disorder under Methadone Maintenance Therapy: Results from a Double-Blind, Randomized, and Placebo-Controlled Trial. Journal of Psychiatric Research, 95, 260-268. https://doi.org/10.1016/j.jpsychires.2017.08.011

[20] Caruso, S., Mauro, D., Cariola, M., Fava, V., Rapisarda, A.M.C. and Cianci, A. (2018) Randomized Crossover Study Investigating Daily versus On-Demand Vulvar Visnadine Spray in Women Affected by Female Sexual Arousal Disorder. Gynecological Endocrinology, 34, 110-114. https://doi.org/10.1080/09513590.2017.1354366

[21] Caputo, A., Natoli, A., Radice, R., Zanardi, G. and Giacomelli, L. (2018) Efficacy of an Intimate Oil Solution Containing Visnadine in Women Self-Reporting Sexual Symptoms. Minerva Ginecologica, 70, 492-493.

[22] McCabe, M.P., Sharlip, I.D., Lewis, R., Atalla, E., Balon, R., Fisher, A.D., Laumann, E., Lee, S.W. and Segraves, R.T. (2016) Incidence and Prevalence of Sexual Dysfunction in Women and Men: A Consensus Statement from the Fourth International Consultation on Sexual Medicine 2015. The Journal of Sexual Medicine, 13, 144-152. https://doi.org/10.1016/j.jsxm.2015.12.034

[23] Fooladi, E. and Davis, S.R. (2012) An Update on the Pharmacological Management of Female Sexual Dysfunction. Expert Opinion on Pharmacotherapy, 13, 2131-2142. https://doi.org/10.1517/14656566.2012.725046

[24] Chubak, B. and Doctor, A. (2018) Traditional Chinese Medicine for Sexual Dysfunction: Review of the Evidence. Sexual Medicine Reviews, 6, 410-418. https://doi.org/10.1016/j.sxmr.2017.11.007

[25] Tadayon, M., Shojaee, M., Afshari, P., Moghimipour, E. and Haghighizadeh, M.H. (2018) The Effect of Hydro-Alcohol Extract of Tribulus terrestris on Sexual Satisfaction in Postmenopause Women: A Double-Blind Randomized Placebo-Controlled Trial. Journal of Family Medicine and Primary Care, 7, 888-892.

[26] Shahid, M., Riaz, M., Talpur, M.M. and Pirzada, T. (2016) Phytopharmacology of Tribulus terrestris. Journal of Biological Regulators and Homeostatic Agents, 30, 785-788.

[27] Szewczyk, K. and Zidorn, C. (2014) Ethnobotany, Phytochemistry, and Bioactivity of the Genus Turnera (Passifloraceae) with a Focus on Damiana-Turneradiffusa. Journal of Ethnopharmacolog, 152, 424-443. https://doi.org/10.1016/j.jep.2014.01.019

[28] Lopresti, A.L. and Drummond, P.D. (2014) Saffron (Crocus sativus) for Depression: A Systematic Review of Clinical Studies and Examination of Underlying Antidepressant Mechanisms of Action. Human Psychopharmacology, 29, 17-27. https://doi.org/10.1002/hup.2434

[29] Rao, S.V., MuralidharaYenisetti, S.C. and Rajini, P.S. (2016) Evidence of Neuroprotective Effects of Saffron and Crocin in a Drosophila Model of Parkinsonism. Neurotoxicology, 52, 230-242. https://doi.org/10.1016/j.neuro.2015.12.010

[30] Laganà, A.S., Vitale, S.G., Stojanovska, L., Lambrinoudaki, I., Apostolopoulos, V., Chiofalo, B., Rizzo, L. and Basile, F. (2018) Preliminary Results of a Single-Arm Pilot Study to Assess the Safety and Efficacy of Visnadine, Prenylflavonoids and Bovine 
Colostrum in Postmenopausal Sexually Active Women Affected by Vulvovaginal Atrophy. Maturitas, 109, 78-80. https://doi.org/10.1016/j.maturitas.2017.12.015

[31] Palacios, S., Soler, E., Ramírez, M., Lilue, M., Khorsandi, D. and Losa, F. (2019) The Effect of a Multi-Ingredient Based Food Supplement on Sexual Function in Women with Low Sexual Desire. BMC Women's Health, 19, Article No. 58. https://doi.org/10.1186/s12905-019-0755-9

[32] Sanchez-Borrego, R., Molero, F., Castaño, R., Castelo-Branco, C., Honrado, M., Jurado, A.R., Laforet, E., Prieto, R., Cabello, F., Larrazabal, M., Sánchez, F., Florido, J. and Mendoza, N. (2014) Spanish Consensus on Sexual Health in Men and Women over 50. Maturitas, 78, 138-145. https://doi.org/10.1016/j.maturitas.2014.02.020

[33] Nayebi, N., Khalili, N., Kamalinejad, M. and Emtiazy, M. (2017) A Systematic Review of the Efficacy and Safety of Rosa damascena Mill with an Overview of Its Phytopharmacological Properties. Complementary Therapies in Medicine, 34, 129-140. https://doi.org/10.1016/j.ctim.2017.08.014

[34] Farnia, V., Tatari, F., Alikhani, M., Shakeri, J., Taghizadeh, M., Karbasizadeh, H., Sadeghi Bahmani, D., Holsboer-Trachsler, E. and Brand, S. (2017) Rosa damascena Oil Improved Sexual Function and Testosterone in Male Patients with Opium Use Disorder under Methadone Maintenance Therapy-Results from a Double-Blind, Randomized, Placebo-Controlled Clinical Trial. Drug and Alcohol Dependence, 176, 117-125. https://doi.org/10.1016/j.drugalcdep.2017.02.008

[35] Steels, E., Rao, A. and Vitetta, L. (2011) Physiological Aspects of Male Libido Enhanced by Standardized Trigonellafoenum-graecum Extract and Mineral Formulation. Phytotherapy Research, 5, 1294-1300. https://doi.org/10.1002/ptr.3360 


\section{Appendix}

\section{SEARCH STRATEGY}

((“"arousal” [MeSH Terms] OR "arousal" [All Fields]) AND ("disease" [MeSH Terms] OR "disease" [All Fields] OR "disorder" [All Fields])) OR (("hypokinesia" [MeSH Terms] OR "hypokinesia" [All Fields] OR "hypoactive" [All Fields]) AND ("libido" [MeSH Terms] OR "libido" [All Fields] OR ("sexual” [All Fields] AND "desire" [All Fields]) OR "sexual desire" [All Fields]))) OR (("female" [MeSH Terms] OR "female" [All Fields]) AND ("sexual behavior" [MeSH Terms] OR ("sexual" [All Fields] AND "behavior" [All Fields]) OR "sexual behavior" [All Fields] OR "sexual" [All Fields]) AND ("physiopathology" [Subheading] OR "physiopathology" [All Fields] OR "dysfunction” [All Fields])) AND (((("biological products" [MeSH Terms] OR ("biological” [All Fields] AND "products" [All Fields]) OR "biological products" [All Fields] OR ("natural”[All Fields] AND "products" [All Fields]) OR "natural products" [All Fields]) OR (soy[All Fields] AND ("oestrogen" [All Fields] OR "estrogens" [Pharmacological Action] OR "estrogens" [MeSH Terms] OR "estrogens" [All Fields] OR "estrogen" [All Fields]))) OR (soy[All Fields] AND ("phytotherapy” [MeSH Terms] OR "phytotherapy" [All Fields]))) OR ("phytotherapy" [MeSH Terms] OR "phytotherapy" [All Fields])) AND (randomized controlled trial [pt] OR controlled clinical trial [pt] OR randomized controlled trials [mh] OR random allocation [mh] OR double-blind method [mh] OR single-blind method [mh] OR clinical trial [pt] OR clinical trials $[\mathrm{mh}]$ OR ("clinical trial [tw] OR ((singl* [tw] OR blind $\left.\left.{ }^{\star}[\mathrm{tw}]\right)\right)$ OR ("latin square" [tw] OR placebo [mh]) OR placebos [mh] OR placebo* [tw] OR random* $\left.{ }^{*} \mathrm{tw}\right]$ OR research design [mh:noexp] OR comparative study [mh] OR evaluation studies [mh] OR follow-up studies [mh] OR prospective studies [mh] OR cross-over studies [mh] OR control ${ }^{\star}[\mathrm{tw}]$ OR prospective* [tw] OR volunteer $[\mathrm{tw}]$ NOT (animal [mh] NOT human $[\mathrm{mh}]$ ). 